\title{
Physiological Response and Protein Expression under Acid Stress of Escherichia coli 0157:H7 TWC01 Isolated from Taiwan
}

\author{
Yu-Ju Huang, Tsung-Yu Tsai, and Tzu-Ming PaN* \\ Institute of Microbiology and Biochemistry, National Taiwan University, \\ Taipei, Taiwan, Republic of China
}

\begin{abstract}
Escherichia coli $\mathrm{O} 157: \mathrm{H} 7$ has an unusually high resistance to acidic environments. Some research has revealed that acid-adapted cells, by exposure to moderately acidic conditions, are more resistant to a subsequent strong acidic challenge or other stress. This study was conducted to understand the protein expression regulation of acid tolerance response (ATR) of a local isolated E. coli O157:H7 TWC01 (TWC01) induced by an acidic environment. TWC01 cells were acid adapted by using hydrochloric acid $(\mathrm{HCl})$ or lactic acid as acidifier to induce ATR. The total proteins of adapted cells were extracted for proteomic analysis and protein identification by matrix-assisted laser desorption ionization quadrupole time-of-flight tandem mass spectrometry (MALDI-Q-TOF MS/MS). Furthermore, the effects of acid adaptation on shiga-like toxin (stx) secretion were examined. Results revealed that acid adaptation depressed stx production of E. coli O157:H7 TWC01 during adaptation and did not improve post-stress toxin production. Image analysis of the gel indicated that numerous proteins were up-regulated and that lactic acid had a greater effect than $\mathrm{HCl}$ did (percentages of up-regulated proteins were 57.64 and $35.47 \%$, respectively). Analysis of proteins by mass spectrometry revealed that most of the up-regulated proteins were metabolism-related, including phosphoglycerate kinase (PGK), glutamate decarboxylases $\alpha$ and $\beta$ (GadA, GadB), adenine phosphoribosyltransferase (APRT), and dihydrodipicolinate synthase (DHDPS). Others were related to translation (e.g., elongation factor $\mathrm{Tu}$, elongation factor $\mathrm{G}$ ), protein folding (e.g., alkyl hydroperoxide reductase), and membrane proteins (e.g., ompA precursor and ompR). The variation of protein expression showed that acid resistance was induced in TWC01 and was primarily manifested via expression of up-regulated proteins that contribute to increased energy conservation and polypeptide synthesis.
\end{abstract}

KEYWORDS: Escherichia coli 0157:H7; acid tolerance response; shiga-like toxin; proteome

\section{INTRODUCTION}

Escherichia coli $\mathrm{O} 157: \mathrm{H} 7$ is one of the most important foodborne pathogens. It can produce shiga-like toxins. E. coli O157:H7 infection will cause variable symptoms from abdominal cramping to severe and bloody diarrhea. In some cases, it can result in complications such as hemorrhagic colitis (HC) (1), hemolytic uremic syndrome (HUS) (2), and thrombotic thrombocytopenic purpura (TTP) (3). Children and the elderly are most affected. In the United States, HUS is the principal cause of acute kidney failure in children. E. coli $\mathrm{O} 157: \mathrm{H} 7$ has an unusually higher resistance to acidic environment than other foodborne pathogens. It can persist in acidic foods including apple cider ( $\mathrm{pH} 3.6-4.0)$ (4-6), fermented sausage (7), fermented dairy products (8), and salad dressing (9). In 2006, two outbreaks of $E$. coli $\mathrm{O} 157: \mathrm{H} 7$ associated with spinach and fast food in the United States attracted public attention of this organism and raised concerns about food safety once again.

* Author to whom correspondence should be addressed (telephone +886 2-3366-4519; fax +886-2-2362-7044; e-mail tmpan@ntu.edu.tw).
Foodborne pathogens are always subjected to all kinds of environmental stress from the farm to the table. Upon ingestion, gastrointestinal acidity can kill nonresistant bacteria. It has been reported that microorganisms have developed mechanisms to adapt to environmental stress $(10,11)$. The ability of pathogens to adapt to and resist stress could increase the risk of foodborne disease. Previous studies revealed that bacteria intentionally adapted to stress not only developed resistance to the challenging condition but may also have developed resistance to other stressors as well $(10,12)$. Foster and Hall (13) reported that Salmonella typhimurium grown at moderate acidic conditions ( $\mathrm{pH} 5.5-6.0)$ could induce acid resistance, which protects the cells from the more extreme acid conditions. This response has been called the adaptive acid tolerance response (ATR). A similar response has been found in E. coli O157:H7. Benjamin and Datta reported that short duration exposure of E. coli O157: $\mathrm{H} 7$ to mild acidic conditions could increase its resistance to more acidic environments (14), which could result in its enhanced survival in acidic foods (15). The adaptation of $E$. 
coli $\mathrm{O} 157: \mathrm{H} 7$ to acidic conditions improves not only its survival in acidic foods but also its chance of surviving gastric acidity (15-17). This may explain its low infectious dose $(18,19)$. In industry applications, low $\mathrm{pH}$ and acid treatment has been used to control pathogen growth in foods. Poor or improper processing could allow E. coli $\mathrm{O} 157: \mathrm{H} 7$ to survive and cause infection. To prevent foodborne disease caused by E. coli O157:H7, knowledge about the acid resistance and ATR of this organism is key.

Proteomic methods are ideal for the analysis of global changes of the cell and have enhanced our knowledge about how regulatory proteins control the stress response. Despite a large amount of knowledge gained in recent years about the mechanisms that $E$. coli uses to deal with and survive in acid stress, there are still many proteins that might be involved in acid tolerance regulation and remain to be discovered. In addition, E. coli $\mathrm{O} 157: \mathrm{H} 7$ is reported to increase the expression of two important virulence factors, shiga-like toxins 1 and $2(20,21)$. This implies that the stress response of E. coli $0157: \mathrm{H} 7$ may not only protect it from death and increase its resistance to subsequent stress conditions but also affect its virulence. In this study, we investigated the protein regulation of ATR of $E$. coli O157:H7 isolated from northern Taiwan. The protein profiles related to ATR were examined by two-dimensional electrophoresis (2-DE) and proteins identified by mass spectrometry. In addition, the effects of acid adaptation to stx secretion were examined also.

\section{MATERIALS AND METHODS}

Bacterial Strains and Growth Conditions. The strain used in this study was the E. coli O157:H7 TWC01 isolated from a clinical patient with bloody diarrhea in Taipei (provided by CDC, Taiwan) (22). Bacteria were cultured in tryptic soy broth (TSB, pH 7.4) or tryptic soy agar (TSA) (Difco Laboratories, Detroit, MI). Frozen stock cultures were activated with two successive transfers in TSB and kept on a TSA plate at $4{ }^{\circ} \mathrm{C}$ for each experiment. The strain was transferred to a new plate to retain viability every 2 weeks during use. The TWC01 cells were cultured in TSB at $37{ }^{\circ} \mathrm{C}$ for $18 \mathrm{~h}$ prior to use. Cultures were confirmed monthly on sorbitol-McConkey agar (SMAC) (Difco). The growth curve in broth culture was measured by optical density at $600 \mathrm{~nm}\left(\mathrm{OD}_{600}\right)$ using a model U-2001 spectrophotometer (Hitachi Co., Tokyo, Japan).

Preparation of Acid-Adapted Cells. Acid adaptation was based on procedures described in references 23 and 24. For adapted ATR analysis, the overnight cultured TWC01 cells were diluted 100 -fold in fresh TSB and grown with agitation to midexponential phase to an $\mathrm{OD}_{600}$ of $0.4-0.5$. Cultures were pelleted at $5000 \mathrm{~g}$ for $10 \mathrm{~min}$. Cells were resuspended in fresh TSB, which was acidified to $\mathrm{pH} 4.5$ by $\mathrm{HCl}$ (HCl-TSB) (Merck, Darmstadat, Germany) or to $\mathrm{pH} 5.5$ by lactic acid (LA-TSB) (Hanawa, Osaka, Japan) and then incubated at $37^{\circ} \mathrm{C}$ for 2 h. The growth was examined by measuring the $\mathrm{OD}_{600}$ every $20 \mathrm{~min}$. Cells incubated in HCl-TSB or LA-TSB for 20 min were collected and used for proteomic analysis. Control cells were resuspended in normal TSB. Cells grown to an $\mathrm{OD}_{600}$ of $1.7-1.8$ were used as stationary phase control.

To evaluate the acid resistance, control and adapted cells were pelleted at $5000 \mathrm{~g}$ for $10 \mathrm{~min}$. The pellete was washed twice by saline and then resuspended in TSB acidified to $\mathrm{pH} 3.0$ by $\mathrm{HCl}$ and incubated for $2 \mathrm{~h}$ at $37^{\circ} \mathrm{C}$. Cultures were serially diluted with saline and plated onto TSA plates and then incubated at $37{ }^{\circ} \mathrm{C}$ for $24 \mathrm{~h}$ prior to counting of colonies. Acid resistance was expressed as survival (percent) by dividing the number of viable cells $(\mathrm{CFU} / \mathrm{mL})$ by the cells of time zero $(\mathrm{CFU} / \mathrm{mL})$ (immediately after challenging to $\mathrm{pH} 3.0$ ).

Stx Assessment. Stx production was analyzed with the RIDASCREEN Verotoxin kit (R-Biopharm AG, Darmstadt, Germany) according to the manufacturer' $\times$ ads instruction. One hundred microliters of cultural supernatant and positive and negative controls were added to microtiter wells and incubated for $1 \mathrm{~h}$ at room temperature $\left(25^{\circ} \mathrm{C}\right)$. The liquid was removed, and $100 \mu \mathrm{L}$ of enzyme conjugate was added to each well and incubated for $30 \mathrm{~min}$ at room temperature. Wells were washed four times with $300 \mu \mathrm{L}$ of washing buffer. Subsequently, 100 $\mu \mathrm{L}$ of substrate/chromogen was added to each well and mixed fully. After incubation for $15 \mathrm{~min}$ at room temperature, $50 \mu \mathrm{L}$ of stop reagent was added to each well, and the absorbance at $450 \mathrm{~nm}$ was measured against an air blank. The threshold value is determined by adding 0.1 unit to the mean absorbance of the negative control. Each test was repeated three times.

Sample Preparation and Two-Dimensional Gel Electrophoresis. The control and adapted cells were pelleted by $5000 \mathrm{~g}$ for $10 \mathrm{~min}$ and washed three times with PBS buffer. The cells were resuspended in lysis buffer, which contained $7 \mathrm{M}$ urea, $2 \mathrm{M}$ thiourea, and $4 \% \mathrm{w} / \mathrm{v}$ 3-[(3-cholamidopropyl)dimethylammonio]-1-propane (CHAPS) (Sigma, St. Louis, MO) and disrupted by sonication (Misonix XL-2020, Farmingdale, NY) on ice for $2 \mathrm{~min}$ (power of 85.5-95 W, $10 \mathrm{~s}$ pulse). After centrifugation at $14000 \mathrm{~g}$ at $4{ }^{\circ} \mathrm{C}$ for $30 \mathrm{~min}$, the supernatant containing protein was collected and $60 \mathrm{mM}$ dithiothreitol (DTT) and $0.5 \%$ immobilized $\mathrm{pH}$ gradient (IPG) buffer, $\mathrm{pH} 4-7$ (both from Amersham Bioscience, Piscataway, NJ) were added. The protein sample was allowed to stand for $1 \mathrm{~h}$ at $4{ }^{\circ} \mathrm{C}$ followed by $15 \mathrm{~min}$ of centrifugation at $14000 \mathrm{~g}$ at $4{ }^{\circ} \mathrm{C}$. Protein concentration was estimated by using a 2D Quant kit (Amersham Biosciences) according to the manufacturer's instruction. For first-dimensional isoelectric focusing (IEF), $250 \mu \mathrm{L}$ of sample containing $300 \mu \mathrm{g}$ of proteins was loaded onto the IPG strip, $\mathrm{pH} 4-7$ (Amersham Biosciences). IEF was carried out via stepwise voltage increment with the following conditions: step 1 rehydration, $30 \mathrm{~V}$ for $12 \mathrm{~h}$; step 2, $250 \mathrm{~V}$ (gradient) for $1 \mathrm{~h}$; step 3, $500 \mathrm{~V}$ for $1 \mathrm{~h}$; step 4, $1000 \mathrm{~V}$ for $1 \mathrm{~h}$; step $5,2000 \mathrm{~V}$ for $1 \mathrm{~h}$; step 6, $4000 \mathrm{~V}$ for $1 \mathrm{~h}$; step 7, $6000 \mathrm{~V}$ for $1 \mathrm{~h}$; step $8,8000 \mathrm{~V}$ for $50 \mathrm{kVh}$; total, $64 \mathrm{kVh}$. After that, the strips were first equilibrated on an orbital shaker for $15 \mathrm{~min}$ in equilibration buffer [50 mM Tris, $\mathrm{pH} 8.8,6 \mathrm{M}$ urea, $30 \% \mathrm{v} / \mathrm{v}$ glycerol, $2 \% \mathrm{w} / \mathrm{v}$ sodium dodecyl sulfate (SDS), and trace bromophenol blue] (all from Sigma except glycerol, which was from Wako, Osaka, Japan) containing 1\% w/v DTT and subsequently in the same buffer with $2.5 \% \mathrm{w} / \mathrm{v}$ iodoacetamide (IAA, Sigma) replacing DTT for another $15 \mathrm{~min}$. The equilibrated strip was then transferred onto the second-dimensional SDS-PAGE gel and sealed with $0.5 \%$ agarose. SDS-PAGE was performed on $12.5 \%$ polyacrylamide gel (13 $\mathrm{cm} \times 13 \mathrm{~cm} \times 1.5 \mathrm{~mm}$ ) at a constant ampere of $10 \mathrm{~mA}$ for $1 \mathrm{~h}$ and at $40 \mathrm{~mA}$ for $3.5 \mathrm{~h}$. Sypro Ruby stain was used for visualization of the 2-DE gel.

Image Analysis. Gel images were captured using a Typhoon 9200 Variable Mode Imager (Amersham Biosciences), and digitalized images were analyzed with PDQuest version 7.3.1 software (Bio-Rad, Hercules, CA) for spot detection, matching, quantification, and comparative analysis. The theoretical molecular mass $\left(M_{\mathrm{r}}\right)$ and $\mathrm{p} I$ values of the 2-DE markers were used to calibrate the $M r$ and $\mathrm{p} I$ of the protein spots in the 2-DE gels. Intensity levels were normalized between gels as a proportion of the total protein intensity detected for the entire gel, and protein quantity of each spot was calculated by integrating the density over the spot area.

In-Gel Tryptic Digestion. The 31 chosen protein spots were manually excised from the gel and cut into $1-2 \mathrm{~mm}^{3}$ gel pieces. The gel pieces were reduced with $50 \mathrm{mM}$ DTE in $25 \mathrm{mM}$ ammonium bicarbonate, $\mathrm{pH} 8.5$, at $37^{\circ} \mathrm{C}$ for $1 \mathrm{~h}$ and subsequently alkylated with $100 \mathrm{mM}$ IAA in $25 \mathrm{mM}$ ammonium bicarbonate, $\mathrm{pH} 8.5$, at room temperature in the dark for $1 \mathrm{~h}$. The pieces were then washed twice with $50 \%$ acetonitrile $(\mathrm{ACN})$ in $25 \mathrm{mM}$ ammonium bicarbonate, $\mathrm{pH}$ 8.5 , for 15 min each time. After that, the pieces were dehydrated with $100 \% \mathrm{ACN}$ for $5 \mathrm{~min}$, dried, and then rehydrated with $10 \mu \mathrm{L}$ of mix solution of $0.0225 \mu \mathrm{g}$ of sequencing grade, modified trypsin (Promega, Madison, WI) in $25 \mathrm{mM}$ ammonium bicarbonate, $\mathrm{pH} 8.5$, followed by incubation in $37^{\circ} \mathrm{C}$ for $16 \mathrm{~h}$. The tryptic peptides were extracted twice with 50\% ACN containing 5\% formic acid for 15 min each time with moderate sonication (on ice). The extracted solutions were pooled and evaporated to dryness under vacuum.

Mass Spectrometry Analysis. Protein spots were subjected to concerted MALDI peptide mass fingerprinting (PMF) and CID MS/ MS analysis for protein identification using a dedicated Q-TOF Ultima 


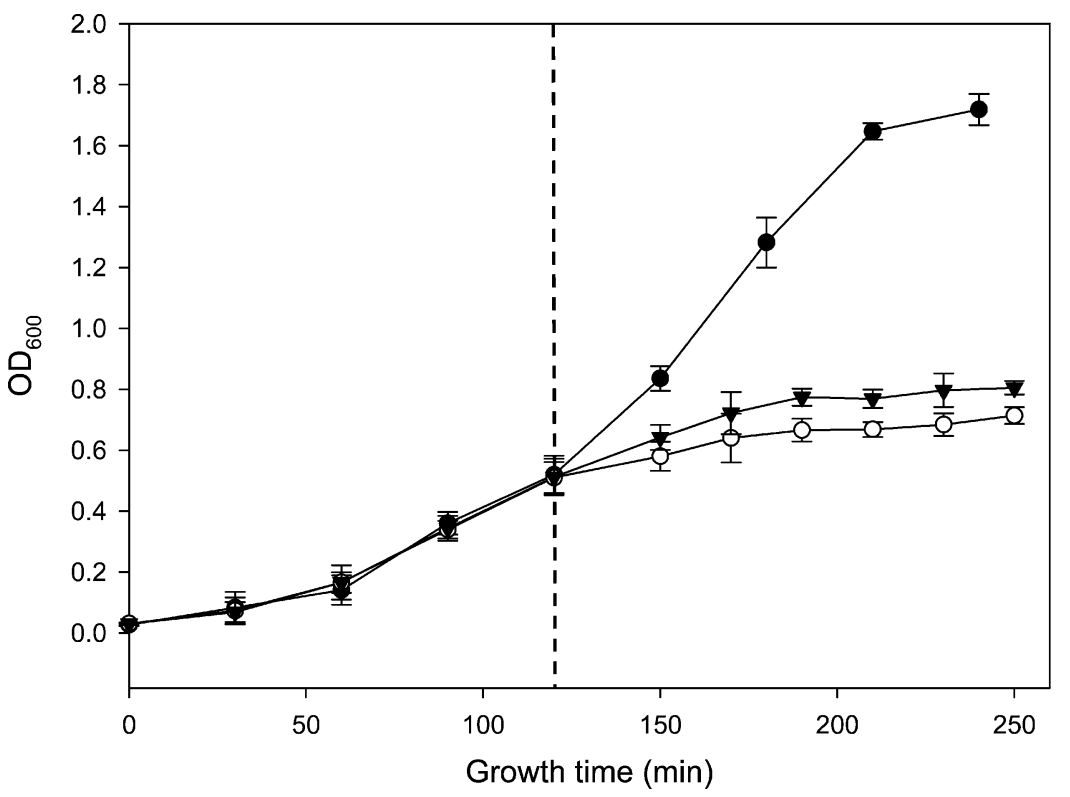

Figure 1. Growth of E. coli O157:H7 TWC01 in response to adaptation by HCl-TSB, pH 4.5 (O); LA-TSB, pH 5.5 ( $\mathbf{\nabla})$; or unadapted control (•). The cells were cultured in TSB (pH 7.4) to an $\mathrm{OD}_{600}$ of $0.4-0.5$ and then transferred to HCl-TSB (pH 4.5), LA-TSB (pH 5.5), or normal TSB as control. The time of medium change is indicated by a dotted line. Error bars represent standard deviation.

MALDI instrument (Micromass, Manchester, U.K.). Samples were premixed $1: 1$ with matrix solution $[5 \mathrm{mg} / \mathrm{mL} \alpha$-cyano-4-hydroxycinnamic acid (CHCA) in 50\% ACN, $0.1 \%$ v/v trifluoroacetic acid (TFA) and $2 \% \mathrm{w} / \mathrm{v}$ ammonium citrate] and spotted onto the 96 well format MALDI sample stage. MALDI MS searched for peaks within $\mathrm{m} / z$ 8003000 , and at a count of more than 150 was switched to CID MS/MS using argon as collision gas. Masses of trypsin peptides occurring at $\mathrm{m} / \mathrm{z} 842.509$ and 2211.104 were used for internal calibration.

Data Search. After data acquisition, the files were searched by querying the SwissPort and NCBI databases using MASCOT (http:// www.matrixscience.com) with the following parameters: peptide mass tolerance, $50 \mathrm{ppm}$; MS/MS ion mass tolerance, $0.25 \mathrm{Da}$; allow up to one missed cleavage. Variable modifications considered were methionine oxidation and cysteine carboxyamidomethylation, taxonomy to $E$. coli. Functions and properties of protein were searched from KEGG (http://www.genome.jp/kegg/) and EcoCyc (http://ecocyc.org/).

\section{RESULTS}

Growth in Response to Acid Adaptation. In previous experiments regarding the growth of TWC01 cells in TSB with different $\mathrm{pH}$ values $(\mathrm{pH} 6.5,5.5,5.0$, and 4.5 acidified by $\mathrm{HCl}$ or LA), results showed that the cell growth was apparently suppressed at $\mathrm{pH} 4.5$ of $\mathrm{HCl}-\mathrm{TSB}$ and at all $\mathrm{pH}$ values of LATSB (data not shown). Hence, we chose $\mathrm{pH} 4.5 \mathrm{HCl}-\mathrm{TSB}$ and $\mathrm{pH}$ 5.5 LA-TSB for acid adaptation. The growth curve in response to acid adaptation is shown in Figure 1. It is found that the growth rates of TWC01 cells were depressed by the $\mathrm{pH}$ shift from $\mathrm{pH} 7.4$ to 4.5 (HCl-TSB) or 5.5 (LA-TSB).

The acid resistance was estimated by challenging control (unadapted) and adapted TWC01 cells with pH 3.0 HCl-TSB at $37^{\circ} \mathrm{C}$ for $2 \mathrm{~h}$ (Figure 2). Stationary phase E. coli O157:H7 cells can also be naturally induced to become acid-tolerant by up-regulated sigma factor RpoS (or $\sigma^{\mathrm{S}}$ ). Therefore, stationary phase cells were also exposed to acid challenge for comparison. Results showed that without adaptation, stationary phase cells have a high $95.69 \%$ survival under $\mathrm{pH} 3.0$, whereas exponential phase cells have only a $0.93 \%$ survival rate. However, after acid adaptation, both $\mathrm{HCl}$ and lactic acid adapted cells were more resistant to $\mathrm{pH} 3.0$ challenge than control cells. The survival of cells adapted by HCl-TSB and LA-TSB was 38.95 and $75.22 \%$,

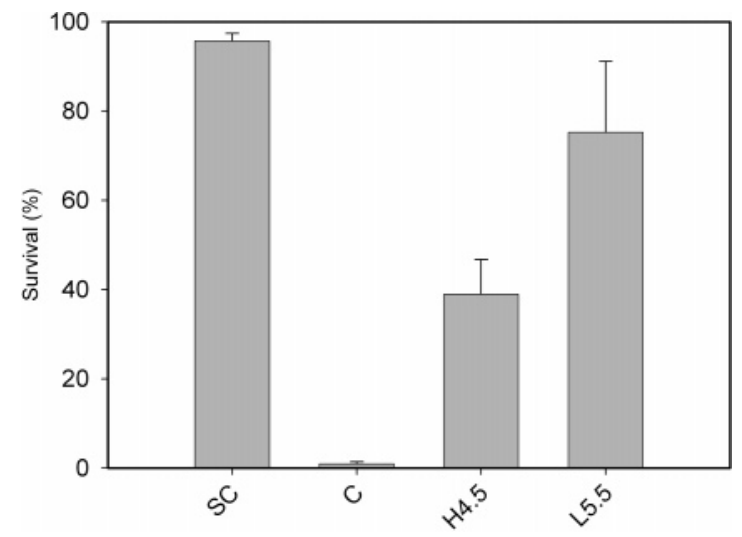

Figure 2. Acid resistance of E. coli 0157:H7 TWC01 cells challenged by $\mathrm{pH} 3.0 \mathrm{HCl}-\mathrm{TSB}$ at $37^{\circ} \mathrm{C}$ for $2 \mathrm{~h}$. SC, unadapted stationary phase cells; $\mathrm{C}$, unadapted exponential phase cells; H4.5, exponential TWC01 cells adapted by $\mathrm{pH} 4.5 \mathrm{HCl}$-TSB for $2 \mathrm{~h}$; L5.5, exponential TWC01 cells adapted by $\mathrm{pH} 5.5 \mathrm{LA}$-TSB for $2 \mathrm{~h}$. The values shown are the means of three independent experiments. Bars indicate standard deviation.

respectively. This suggests that the ATR of TWC01 cells was induced by exponential adapting.

Effect of Acid Adaptation on Stx Production. Stx production was estimated on the basis of the ELISA method. The supernatant from the culture was used for analysis. To ascertain whether the acidic medium had destroyed the toxin, the $\mathrm{pH} 4.5$ HCl-TSB or $\mathrm{pH}$ 5.5 LA-TSB was 1:1 mixed with positive control (stx). The mixtures were incubated for $2 \mathrm{~h}$ at $37^{\circ} \mathrm{C}$ and then analyzed for stx quantity. As shown in Figure 3 A, although at a lower quantity than the positive control, the stx was detectable no matter which medium was used. The results showed that acid condition did not affect stx detection. The influence of acid adaptation to stx secretion is shown in Figure 3B. The stx secretions of adapted TWC01 cells with or without $8 \mathrm{~h}$ of enrichment were compared. It is clearly shown that stx secretion of the adapted cells was depressed during acid adaptation without the enrichment. The stx amount of control cells increased dramatically as time increased, but increased only 

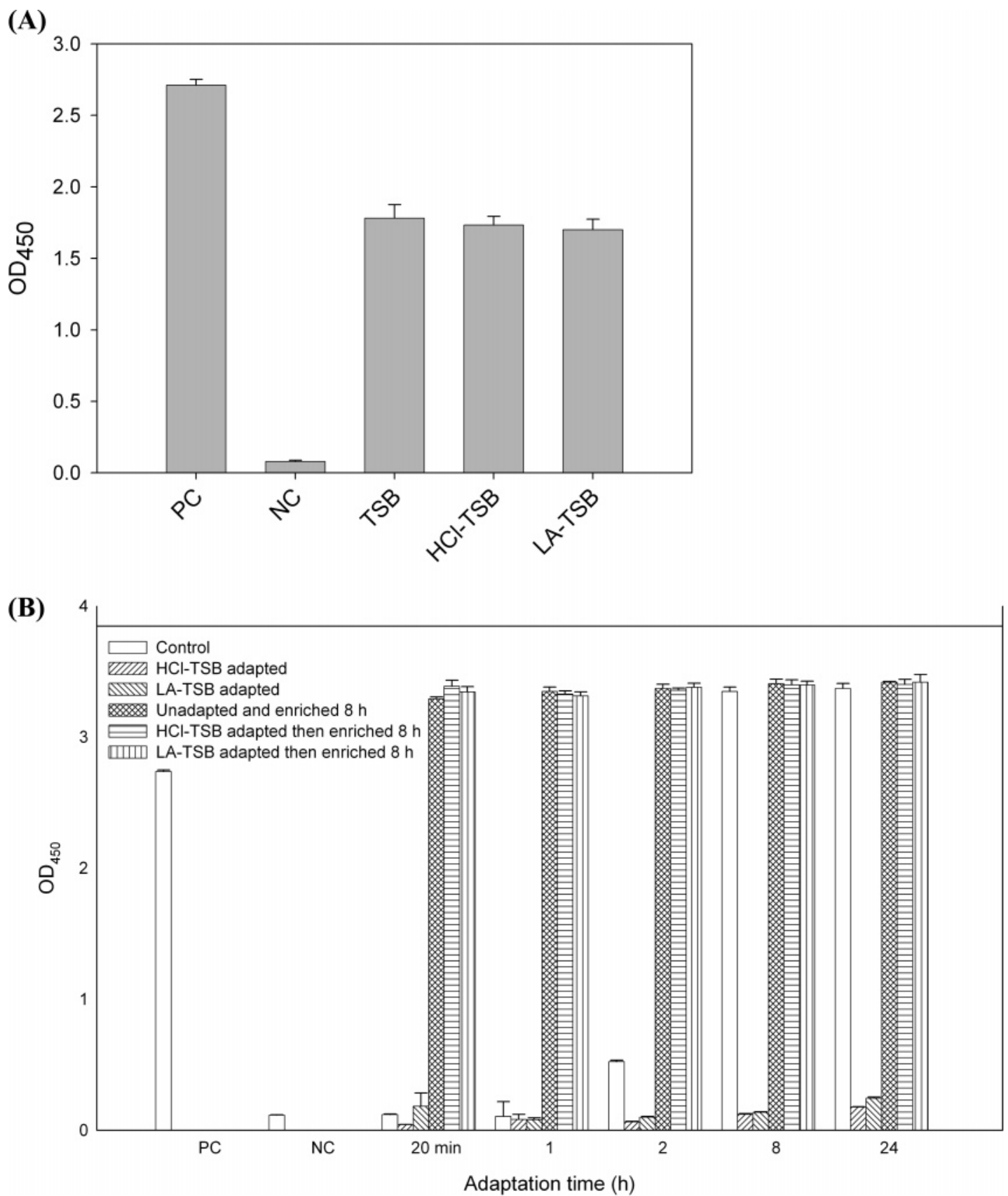

Figure 3. Effect of acid adaptation on stx secretion. (A) Effect of adapted medium on stx was measured by 1:1 mixing positive control with different media and incubated for $2 \mathrm{~h}$. TSB, positive control mixed with normal TSB; HCl-TSB, positive control mixed with pH 4.5 TSB acidified by HCl; LA-TSB, positive control mixed with pH 5.5 TSB acidified by LA. (B) Stx secretion of E. coli 0157:H7 TWC01 cells after acid adaptation with/without 8 h of enrichment in TSB (pH 7.4) at $37^{\circ} \mathrm{C}$. Error bars represent standard deviation. PC, positive control; NC, negative control.

slightly in the adapted cells. However, after enrichment, there was no difference of stx amount between control and adapted cells. The result indicated that stx production of E. coli O157: H7 was depressed in acid environment but had no difference in poststress toxin production.

Change in Protein Expression Patterns after Acid Adaptation. The acid adaptation effect on protein expression of $E$. coli $\mathrm{O} 157: \mathrm{H} 7$ was examined by proteomic analysis. The 2-DE gel analysis of the adapted and control cells is shown in Figure 4. Gels from each different treatment from three independent experiments were analyzed by PDQuest software. Comparing protein expression by HCl-TSB-grown cells with control revealed differential expression ( $>2$-fold) for $35.47 \%$ of the resolved proteins. Among these $24.14 \%$ are up-regulated and $11.33 \%$ are down-regulated. As for LA-TSB-adapted cells, there are $57.64 \%$ of proteins, $>2$-fold; $52.22 \%$ are up-regulated, and only $5.42 \%$ are down-regulated. This suggested that acid adaptation mainly results in up-regulated proteins, especially in LA-TSB-adapted cells. The 31 protein spots with significantly differential expression (up-regulation $>3$-fold or down-regulation $>2$-fold) compared to the control were indicated in gels with spot number and identified by MS/MS. The MASCOT search results and details of these proteins are listed in Table 1. Of the 31 identified protein spots, 28 proteins have known function. Among these proteins, 21 are related to metabolic proteins, 5 are related to genetic information processing, and 2 are related to environmental information processing. Two of these metabolic proteins are related to genetic information processing and environmental information processing, respectively, in addition to metabolic function. 

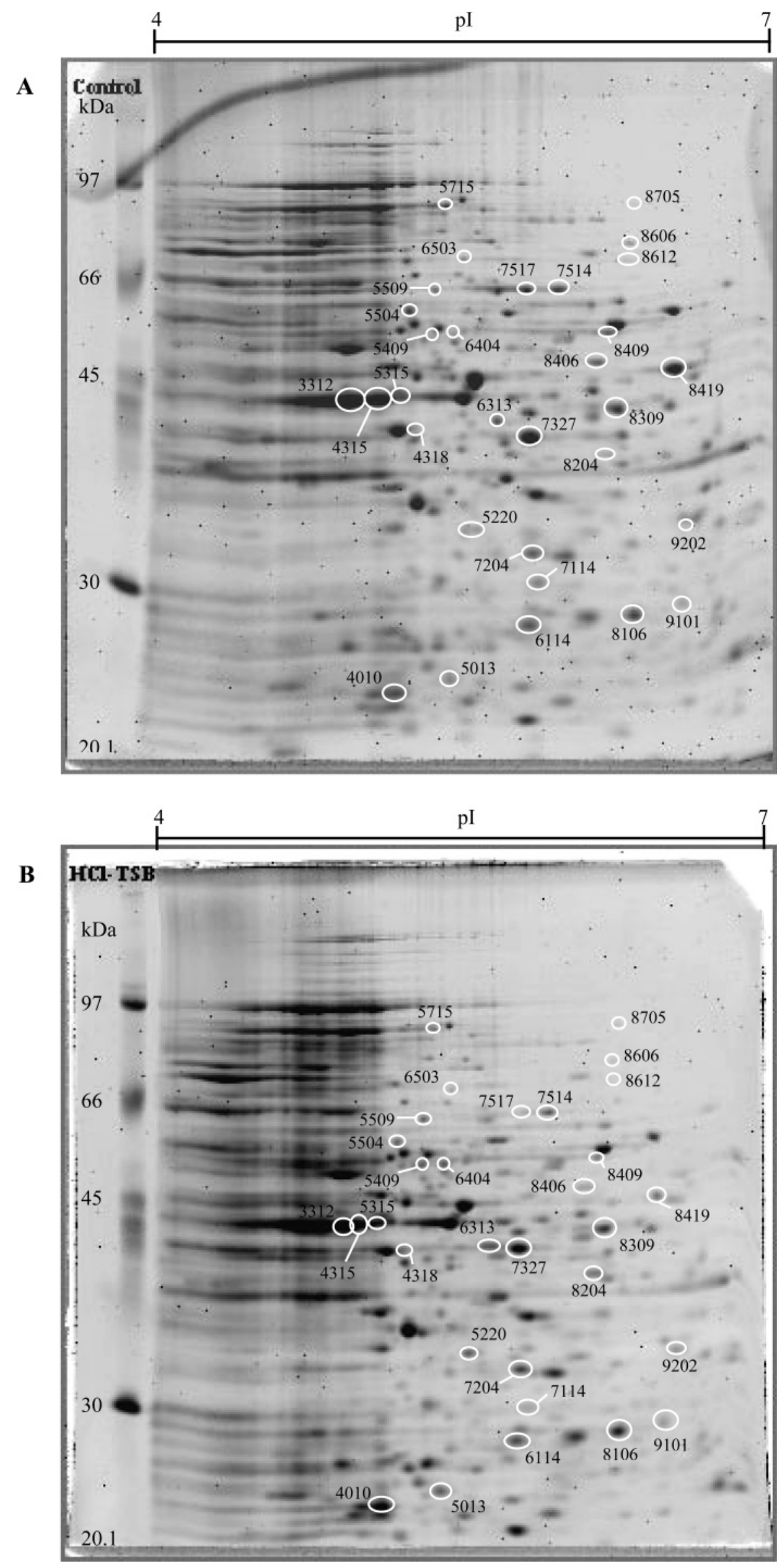


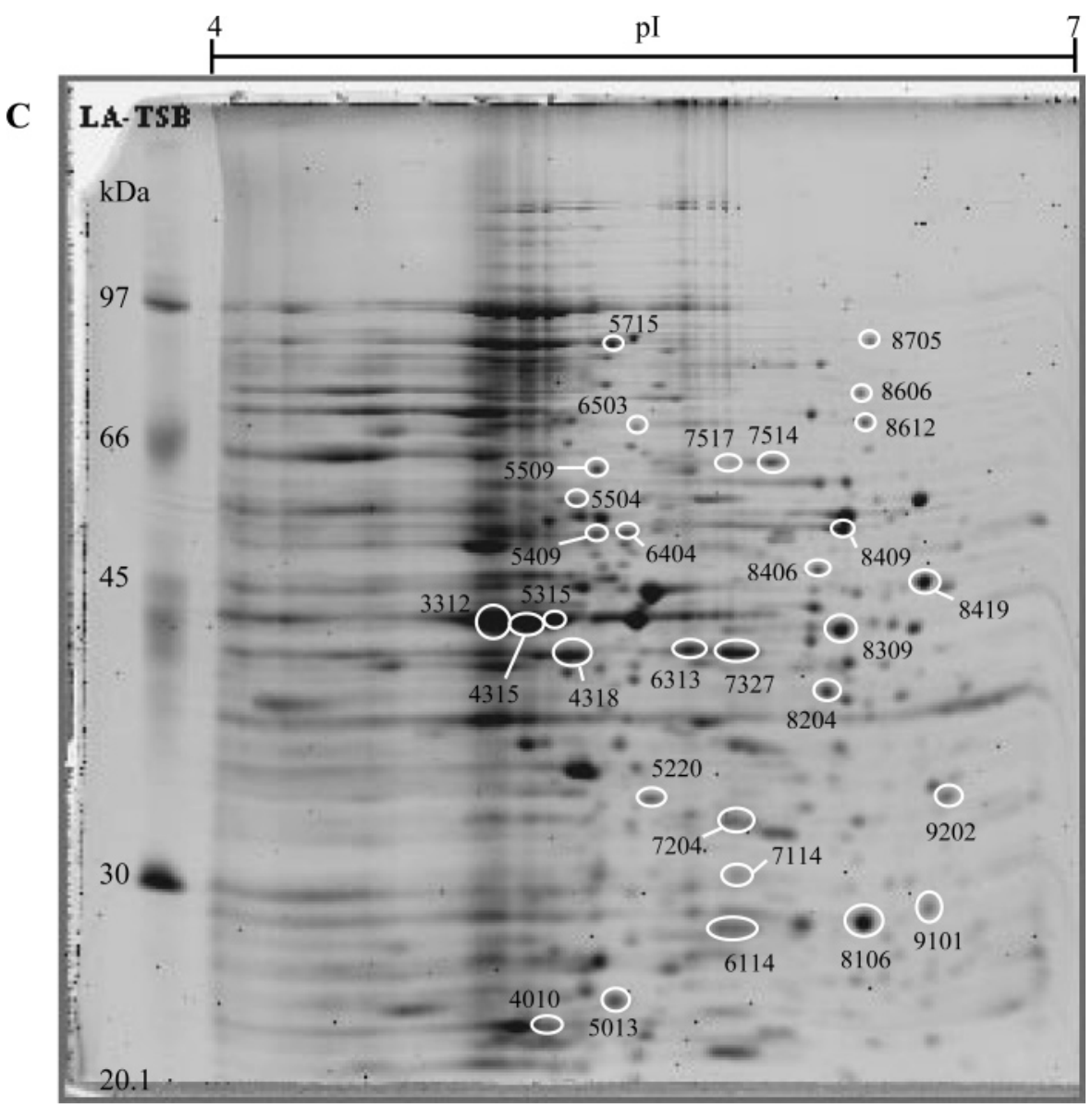

Figure 4. Comparative 2-DE gel analysis of E. coli 0157:H7 TWC01 of unadapted control (A), acid adapted by HCl-TSB, pH 4.5 (B), or acid adapted by LA-TSB, pH $5.5(\mathbf{C})$ at $37{ }^{\circ} \mathrm{C}$ for 20 min. Protein extracts $(300 \mu \mathrm{g} / 250 \mu \mathrm{L})$ of $E$. coli 0157:H7 TWC01 are displayed across a linear IPG strip (pH $4-7,13 \mathrm{~cm}$ ) in the first dimension and a 12.5\% SDS-PAGE in the second dimension, stained with Sypro Ruby. Isoelectric point (p/) and molecular mass $\left(M_{r}\right)$ are marked on horizontal and vertical axes, respectively. Among the protein spots analyzed with the PDQuest program, 31 spots exhibiting different expression levels are indicated by white circles and numbers. Details of the proteins are given in Table 1.

Quantification of protein expression is shown in Figure 5. Most proteins in LA-TSB gel have greater expression than in HCl-TSB gel. Only fructose-bisphosphate aldolase class 2, adenylate kinase, tetrahydrodipicolinate succinylase, and alkyl hydroperoxide reductase subunit $\mathrm{C}$ have more expression in $\mathrm{HCl}$-TSB gel than in LA-TSB. Proteins up-regulated in both acid-adapted gels include phosphoglycerate kinase (PGK), 2,3bisphosphoglycerate-dependent phosphoglycerate mutase (dPGM), glutamate decarboxylases $\alpha(\mathrm{GadA})$ and $\beta(\mathrm{GadB})$, adenine phosphoribosyltransferase (APRT), aspartate aminotransferase, dihydrodipicolinate synthase, alkyl hydroperoxide reductase subunit $\mathrm{C}$, elongation factor $\mathrm{Tu}$ (EF-Tu), ompR, and three hypothetical proteins. Down-regulation proteins in both acidadapted gels are bifunctional purine biosynthesis protein purH, serine hydroxymethyltransferase, adenylosuccinate lyase, EF$\mathrm{Tu}$ (isoform), and outer membrane protein A precursor. It revealed that most of the carbohydrate and amino acid metabolism proteins are up-regulating and down-regulating in nucleotide metabolism proteins.

\section{DISCUSSION}

The influence of acid adaptation by $\mathrm{HCl}$ and lactic acid on physiological response and protein expression of E. coli O157: H7 TWC01 isolated from Taiwan was investigated using a proteomic method. Previous studies reported that local E. coli O157:H7 strains did exist in Taiwan and that they are significantly different in genotype from foreign strains (25).
Therefore, to control the infection and the spread of this pathogen in Taiwan, studies about the characteristics of the $E$. coli $\mathrm{O} 157: \mathrm{H} 7$ isolated in Taiwan are important tasks. According to our precursory experiments, TWC01 has no difference in acid tolerance with five environmental strains (data not shown). Because our goal is to investigate the protein regulation under acid condition of $E$. coli $\mathrm{O} 157: \mathrm{H} 7$ isolated from Taiwan, the clinical strain should represent other local O157:H7 strains.

There are numerous data about ATR for foodborne pathogens including $E$. coli $(10,13,26,27)$. The studies indicated that the physiological responses to acid adaptation implicate the ability of bacteria to modulate the amount and activity of enzymes, which were usually presented by changing protein expression profile. The response let cells habituate to acid and protected it from the lethal effects of acidity. It is known that stationary phase E. coli $\mathrm{O} 157: \mathrm{H} 7$ possesses a stress regulation system, which is regulated by stationary phase sigma factor RpoS (or $\sigma^{S}$ ) (28). In exponential phase E. coli O157:H7, it has been shown that cultured cells in moderate acid condition can induce ATR and help to resist extremely acidic environments. In this study, after adaptation by HCl-TSB or LA-TSB, the survival of exponential phase TWC01 cells under $\mathrm{pH} 3.0$ conditions was apparently increased in comparison with control cells (Figure 2). In an exception to resisting extreme $\mathrm{pH}$, Leyer et al. (15) reported that $E$. coli $\mathrm{O} 157: \mathrm{H} 7$ cells adapted by $\mathrm{pH}$ 5.0 HCl-TSB survived better in salami. However, Tsai and Ingham (16) found that adaptation to acidic condiments $(\mathrm{pH}$ 
Table 1. Proteins Isolated from 2-DE Gel of E. coli 0157:H7 TWC01 and Identified by MALDI-TOF/TOF MS Analysis ${ }^{a}$

\begin{tabular}{|c|c|c|c|c|c|c|c|c|c|c|}
\hline $\begin{array}{l}\text { spot } \\
\text { no. }\end{array}$ & protein name & $\begin{array}{l}\text { gene } \\
\text { name }\end{array}$ & $\begin{array}{l}\text { no. of } \\
\text { matched } \\
\text { peptides }\end{array}$ & $\begin{array}{l}\text { accession } \\
\text { no. }\end{array}$ & $\begin{array}{l}\text { MASCOT } \\
\text { score }\end{array}$ & $\begin{array}{l}\text { sequence } \\
\text { coverage } \\
(\%)\end{array}$ & source & $\begin{array}{c}M_{\mathrm{r}}(\mathrm{kDa}) \\
\text { theor/exptl }\end{array}$ & $\begin{array}{c}\mathrm{p} / \\
\text { theor/exptl }\end{array}$ & function \\
\hline 3312 & elongation factor Tu (EF-Tu) & tufA & 4 & P0A6N3 & 233 & 14 & E. coli & $43.16 / 44.54$ & $5.30 / 5.13$ & genetic information processing \\
\hline 4010 & alkyl hydroperoxide reductase subunit C & ahpC & 4 & P0AE10 & 181 & 37 & E. coli & $20.62 / 23.95$ & $5.03 / 5.21$ & genetic information processing \\
\hline 4315 & elongation factor Tu (EF-Tu) & tufA & 4 & POA6N3 & 233 & 14 & E. coli & $43.16 / 44.54$ & $5.30 / 5.26$ & genetic information processing \\
\hline 4318 & phosphoglycerate kinase & $\mathrm{pgk}$ & 5 & Q8XD03 & 482 & 21 & E. coli & $40.97 / 42.42$ & $5.08 / 5.38$ & metabolism \\
\hline 5013 & adenine phosphoribosyltransferase (APRT) & apt & 2 & Q8XD48 & 134 & 18 & 0157 & $19.86 / 24.95$ & $5.26 / 5.54$ & metabolism \\
\hline 5220 & hypothetical protein yfeX & yfeX & 1 & P76536 & 31 & 6 & E. coli & $33.03 / 34.06$ & $5.34 / 5.68$ & hypothetical protein \\
\hline 5315 & elongation factor Tu (EF-Tu) & tufA & 4 & P0A6N3 & 233 & 14 & E. coli & $43.16 / 44.72$ & $5.30 / 5.33$ & genetic information processing \\
\hline 5409 & glutamate decarboxylase $\alpha$ (GAD- $\alpha)$ & $\operatorname{gad} A$ & 1 & P58228 & 10 & 4 & E. coli 06 & $52.67 / 54.02$ & $5.23 / 5.48$ & metabolism \\
\hline 5504 & $\begin{array}{l}\text { 2,3-bisphosphoglycerate-independent } \\
\text { phosphoglycerate mutase }\end{array}$ & gpml & 1 & Q8XDE9 & 28 & 2 & 0157 & $56.07 / 58.23$ & $5.18 / 5.40$ & metabolism \\
\hline 5509 & NAD-dependent malic enzyme (NAD-ME) & $\operatorname{sfc} A$ & 2 & Q8XAS9 & 183 & 6 & 0157 & $63.16 / 62.32$ & $5.24 / 5.48$ & metabolism \\
\hline 5715 & elongation factor $\mathrm{G}$ (EF-G) & fusA & 5 & POA6NO & 284 & 11 & 0157 & $77.40 / 87.07$ & $5.24 / 5.53$ & genetic information processing \\
\hline 6114 & adenylate kinase (AK) & adk & 2 & P69442 & 61 & 18 & 0157 & $23.57 / 27.90$ & $5.55 / 5.91$ & metabolism \\
\hline 6313 & Aapartate aminotransferase (ASPAT) & aspC & 4 & P00509 & 208 & 18 & E. coli & $43.57 / 42.86$ & $5.8 / 5.79$ & metabolism \\
\hline 6404 & glutamate decarboxylase $\beta$ (GAD- $\beta$ ) & $\operatorname{gadB}$ & 2 & P69911 & 29 & 7 & 0157 & $52.63 / 54.13$ & $5.29 / 5.58$ & metabolism \\
\hline 6503 & $2^{\prime}, 3^{\prime}$-cyclic-nucleotide $2^{\prime}$-phosphodiesterase & $\mathrm{cpdB}$ & 1 & P08331 & 22 & 1 & E. coli & $70.79 / 69.08$ & $5.45 / 5.61$ & metabolism \\
\hline 7114 & outer membrane protein $\mathrm{A}$ & ompA & 3 & P0A911 & 147 & 17 & 0157 & $37.18 / 30.29$ & $5.99 / 5.95$ & environmental information processing \\
\hline 7204 & tetrahydrodipicolinate succinylase & dapD & 4 & Q8X8Y7 & 221 & 25 & 0157 & $29.86 / 32.91$ & $5.55 / 5.93$ & metabolism \\
\hline 7327 & fructose-bisphosphate aldolase class 2 & fbaA & 4 & P0AB72 & 302 & 17 & 0157 & $38.99 / 42.67$ & $5.52 / 5.93$ & metabolism \\
\hline 7514 & CTP synthase & pyrG & 5 & POA7E7 & 243 & 13 & 0157 & $60.21 / 63.28$ & $5.63 / 6.08$ & metabolism \\
\hline 7517 & $\begin{array}{l}\text { bifunctional purine biosynthesis } \\
\text { protein purH }\end{array}$ & purH & 3 & Q8X611 & 169 & 6 & 0157 & $57.32 / 63.16$ & $5.53 / 5.93$ & metabolism \\
\hline 8106 & $\begin{array}{l}\text { 2,3-bisphosphoglycerate-dependent } \\
\text { phosphoglycerate mutase }\end{array}$ & gpmA & 4 & P62709 & 160 & 18 & 0157 & $28.41 / 28.11$ & $5.86 / 6.39$ & metabolism \\
\hline 8204 & hypothetical oxidoreductase & yqhD & 2 & Q46856 & 83 & 4 & E. coli & $42.07 / 40.18$ & $5.72 / 6.26$ & hypothetical protein \\
\hline 8309 & acetate kinase & ackA & 5 & P0A6A5 & 252 & 23 & 0157 & $43.26 / 44.13$ & $5.85 / 6.31$ & metabolism \\
\hline 8406 & adenylosuccinate lyase (ASL) & purB & 4 & P0AB89 & 206 & 12 & E. coli & $51.51 / 50.02$ & $5.68 / 6.23$ & metabolism \\
\hline 8409 & dihydrolipoyl dehydrogenase & IpdA & 3 & P0A9P2 & 180 & 11 & 0157 & $50.53 / 54.47$ & $5.79 / 6.32$ & metabolism \\
\hline 8419 & serine hydroxymethyltransferase (SHMT) & glyA & 3 & Q8XA55 & 222 & 14 & 0157 & $45.32 / 48.62$ & $6.41 / 6.59$ & metabolism \\
\hline 8606 & fumarate reductase flavoprotein subunit & frdA & 1 & P00363 & 85 & 2 & E. coli & $65.80 / 75.97$ & $5.87 / 6.38$ & $\begin{array}{l}\text { metabolism and environmental } \\
\text { information processing }\end{array}$ \\
\hline 8612 & glutaminyl-tRNA synthetase (GInRS) & $g \ln S$ & 1 & Q8X9H8 & 21 & 2 & 0157 & $63.34 / 69.96$ & $5.88 / 6.39$ & $\begin{array}{l}\text { metabolism and genetic } \\
\text { information processing }\end{array}$ \\
\hline 8705 & protein yhgF & yhgF & 1 & P46837 & 34 & 2 & E. coli & $85.07 / 87.87$ & $5.92 / 6.41$ & hypothetical protein \\
\hline 9101 & transcriptional regulatory protein ompR & ompR & 2 & P0AA18 & 36 & 12 & 0157 & $27.34 / 28.78$ & $6.04 / 6.61$ & environmental information processing \\
\hline 9202 & dihydrodipicolinate synthase (DHDPS) & dapA & 2 & P63944 & 115 & 13 & 0157 & $31.26 / 34.16$ & $5.98 / 6.67$ & metabolism \\
\hline
\end{tabular}

a Spot numbers, experimental molecular mass $\left(M_{\mathrm{r}}\right)$, and $\mathrm{p} /$ were assigned using PDQuest version 7.3.1 software from 2-DE gel. Theoretical $M_{\mathrm{r}}$ and $\mathrm{p} /$ were from the database. The function of protein is catalog according to KEGG and EcoCyc.

5.0) improved the survival in ketchup but not in mustard or relish. As a result, the ATR induced by acid adaptation may have differences with respect to growth condition, medium, and acidulent.

In this work, we used inorganic $(\mathrm{HCl})$ and organic (lactic acid) acid as acidulent. Previous study showed that lactic acid has more antibacterial ability than $\mathrm{HCl}$ (data not shown). It is known that the antibacterial effect of organic acid is due to the undissociated molecules, which can be passed through the cell membrane much easily than proton. Once in the cell, molecules are ionized and release protons in the cytoplasm, thereby depressing intracellular $\mathrm{pH}$ and inhibiting metabolism (29). In addition, $E$. coli is equipped with several acid resistance (AR) systems, including decarboxylase-dependent acid resistance. This kind of AR is potentially electrogenic during the antiport exchanging the decarboxylated molecules. For example, the arginine has a +1 charge at $\mathrm{pH} 2.5$, but after decarboxylation will become agmatine and produce a +2 charge. Exchanging intracellular +2 agmatine with extracellular +1 arginine will remove a net +1 charge from the cell and result in hyperpolarization of the membrane. As a solution of this situation, Iyer and co-workers (30) struck out the ClC chloride channel model. They hypothesized that the $\mathrm{ClC}$ transport protein of the channel would remove the $\mathrm{Cl}^{-}$from the cell and neutralize membrane electric potential. This model relied on the small amount of extracellular undissociated $\mathrm{HCl}$ in low-pH solution. Therefore, the undissociated $\mathrm{HCl}$ molecule in $\mathrm{HCl}-\mathrm{TSB}(\mathrm{pH} 4.5)$ may be used by the $\mathrm{ClC}$ chloride channel model against acid stress. Hence, the cells can better resist inorganic acid than organic acid.

Shiga-like toxin is important for pathogenicity of $E$. coli O157:H7. The toxin needs to be transported through the membrane to an extracellular location before it can work. Environmental stresses are known to change membrane lipid composition and affect its function (31). Yuk and Marshall (32) reported that the alteration of membrane lipid composition, which was caused by high growth temperature and acid adaptation, influenced verotoxin secretion. Also, the stationary phase sigma factor RpoS not only regulates the stress response of stationary phase cells but also has implications in virulence (33). Wilmes-Riesenberg et al. (34) discovered that the acid resistant mutant strain of $S$. typhimurium had a slightly increased virulence in comparison with the parent strain. As a result in our study, the ATR was induced in acid-adapted TWC01 cells. We hypothesized that adapted acid tolerance regulation might effect stx production. The quantification results showed that stx quantity was inhibited during acid adaptation despite adaptation by HCl-TSB or LA-TSB, which is an identical result to the study by Yuk and Marshall $(32,35)$. In their investigations, $E$. coli $\mathrm{O} 157: \mathrm{H} 7$ cells adapted by $\mathrm{HCl}$ or organic acids were detrimental in membrane fluidity and verotoxin secretion. The explanation for this is that to resist the acid environment, cells will reduce the membrane fluidity to decrease protons from flowing into cytoplasm, which results in decreasing stx secretion. On the other hand, presented results indicate that acid adaptation 


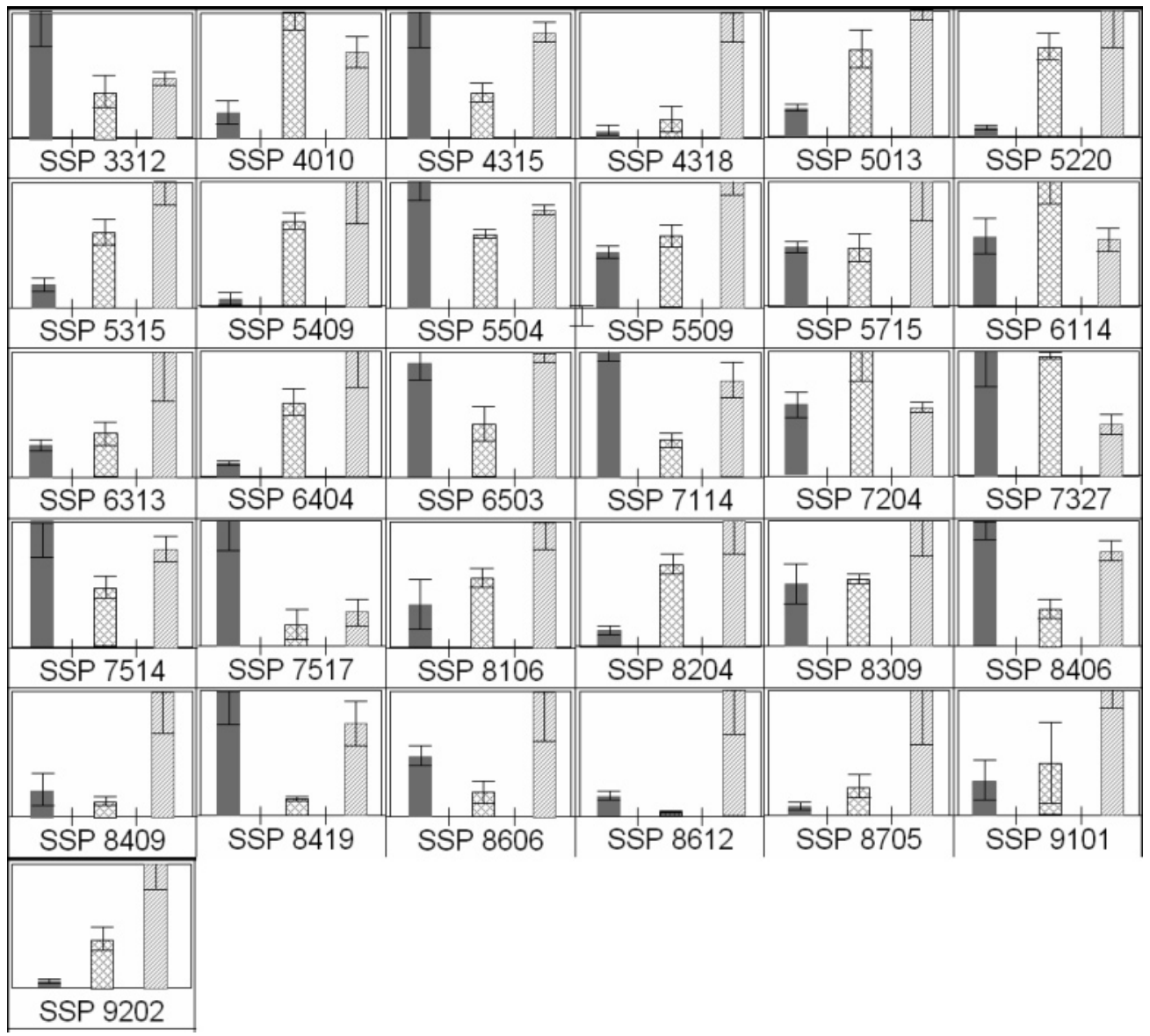

Figure 5. Quantification of protein expression under different acid adaptations. The gels of control (solid bars), adapted by HCl-TSB (cross-hatched bars), and adapted by LA-TSB (slashed bars) were analyzed using PDQuest version 7.3.1 software, and the relative abundance ratio of proteins was determined. SSP numbers correspond to spot numbers on 2-DE gels. The results of 2-DE analysis of each growth culture were performed in triplicate. Error bars represent standard deviation.

does not improve the poststress toxin production. Leenanon et al. (36) also reported that the expression of stx2 mRNA increased for acid-adapted cells, but it does not increase the production of mature stx. In conclusion, although acid adaptation increased stx 2 mRNA expression of $E$. coli $\mathrm{O} 157: \mathrm{H} 7$, the mature toxin was blocked due to the decrease of membrane fluidity resulting from acid ataptation. Furthermore, acid adaptation does not appear to affect poststress stx production. However, the kit used in this study could not differentiate two stx. It may be possible that acid stress could affect the proportion of stx 1 to stx2, and therefore more experiments are needed.

Proteomics analysis of proteins with different expressions reveals that most of the identified proteins were metabolism related. The metabolism-related proteins can be divided into three main subgroups: carbohydrate metabolism, nucleotide metabolism, and amino acid metabolism. Carbohydrate metabolism related proteins include PGK, 2,3-bisphosphoglycerateindependent phosphoglycerate mutase (iPGM), dPGM, dihydrolipoyl dehydrogenase, fumarate reductase flavoprotein subunit, fructose-bisphosphate aldolase class 2, acetate kinase, NADdependent malic enzyme, GadA, and GadB. Most of the enzymes participate in glycolysis, TCA cycle, and/or pyruvate metabolism. According to relative expression of protein spots (Figure 5), a great number of carbohydrate metabolism related proteins are up-regulated except the fumarate reductase flavoprotein subunit of HCl-TSB gel and fructose-bisphosphate aldolase class 2 of LA-TSB gel. In glycolysis, the function of PGK is to catalyze 1,3-bisphosphoglycerate to 3-phosphoglycerate and use ADP to produce ATP. The Pgk gene has been found to show growth phase regulation; the synthesis of PGK protein was induced $>10$-fold during transition from the exponential to the stationary growth phase (37). In comparison with our present study, TWC01 cells used for proteomics analysis are in the exponential phase. The increased expression of PGK may be because of the growth need. However, Leistner (38) reported that bacteria exposed to stress would increase the energy consumption, which suggests that the increased expression of PGK and other carbohydrate metabolism related proteins may be related to acid stress. iPGM and dPGM can catalyze the interconversion of 2-phosphoglycerate and 3-phosphoglycerate. dPGM has a 10 times higher specific activity compared with iPGM (39). The expression of dPGM increased in both acid-adapted cells, suggesting that under acid environment $E$. coli $\mathrm{O} 157: \mathrm{H7}$ is preferred over dPGM due to the higher efficiency.

GadA and GadB are related to AR2 (glutamate-dependent acid resistant system) of $E$. coli, which maintains the intracellular $\mathrm{pH}$ within 4.2. Marie-Pierre and Foster (40) proved that GadA and GadB were induced in acid environment. In our study, these two proteins were up-regulated in both acid-adapted cells. The result reveals the induction of AR of $E$. coli $\mathrm{O} 157: \mathrm{H} 7$ during acid adaptation to deal with acid stress.

Nucleotide metabolism related proteins include APRT, adenylate kinase $(\mathrm{AK})$, bifunctional purine biosynthesis protein purH, adenylosuccinate lyase, CTP synthase, and 2',3'-cyclicnucleotide 2 '-phosphodiesterase (precursor). Among these proteins only APRT is up-regulated in acid-adapted cells. This enzyme can use purine and pyrimidine from nucleotide degrada- 
tion to produce AMP, which needs less energy than the direct synthesis of AMP. The up-regulation of APRT may help cells to reduce energy consumption and prevent exhaustion.

Amino acid metabolism related proteins include aspartate aminotransferase (AspAT), tetrahydrodipicolinate succinylase, dihydrodipicolinate synthase (DHDPS), and serine hydroxymethyltransferase (SHMT). The AspAT participates in aspartate synthesis and can be used to produce $\mathrm{NAD}^{+}$, which is a cofactor to initiate the electron transport chain by the reaction with an organic metabolite (intermediate in metabolic reactions). In LATSB gel, up-regulation of AspAT implicates organic acid in the improvement of the metabolic reactions of $E$. coli O157: $\mathrm{H} 7$. The result of that is the generation of more energy to aid acid resistance. DHDPS is related to the biosynthesis of lysine, which leads to lysine-dependent AR of E. coli. Up-regulation of both acid-adapted cells reveals that another acid resistance mechanism is induced during adaptation.

Besides metabolism-related proteins, genetic information processing related proteins are discovered during acid adaptation. Elongation factor $\mathrm{Tu}(\mathrm{EF}-\mathrm{Tu})$ and its isoform, elongation factor G (EF-G), and glutaminyl-tRNA synthetase (GluRS) are translation-related proteins and are needed for protein synthesis. EF$\mathrm{Tu}$ and EF-G are GTP-dependent elongation factors, and they are responsible for binding of aminoacyl tRNA to rRNA and translocation, respectively. GluRs is responsible for ligation of glutamine and tRNA. Up-regulation of these proteins was observed in LA-TSB-adapted cells. The results revealed that under acid condition, TWC01 cells tend to increase production of glutamine, which can convert into glutamate and be used for glutamate-dependent AR. However, the phenomenon did not show in HCl-TSB-adapted cells. The studies need more experiments to interpret that. Another interesting discovery is EF-Tu. This protein is encoded by tufA and can promote the GTP-dependent binding of aminoacyl-tRNA to the A-site of ribosomes during protein biosynthesis (Swiss-Prot). We found that there are three different spots all identified as EF-Tu (spots 3312 , 4315, and 5315). Only spot 5315 is up-regulated in acidadapted cells, as others are down-regulated. This reveals that modification of EF-Tu tended to increase $\mathrm{p} I$ during acid adaptation.

The third group of identified proteins is environmental information processing related proteins and includes outer membrane protein A precursor (OmpA precursor) and transcriptional regulatory protein ompR. OmpA is one of the most abundant proteins of the outer membrane of E. coli. It is considered as a nonspecific diffusion channel, which allows many kinds of small molecules to pass through the membrane (41). Down-regulation of OmpA was discoveried in HCl-TSBadapted cells. The result is identical with the Sainz et al. (42) study. According to their finding, the explanation was predicted to be growth inhibition caused by stress and indirectly affected the production of OmpA.

OmpR belongs to the two-component regulatory system EnvZ/OmpR. This regulatory system is responsible for regulating the transcription of genes of other membrane proteins, which include ompC and ompF. In addition, the two-component system is also thought to be a regulatory system of bacteria to sense environmental stresses. A sensor molecule (usually in the membrane) is used for sensing signals from the environment. In response to that signal, the intracellular regulator will be activated (43). This protein clearly increases in LA-TSB-adapted cells but only slightly in HCl-TSB-adapted cells (1.5-fold). This reveals that the resistance induced by LA-TSB adaptation is likely regulated by the two-component system but not for $\mathrm{HCl}$ TSB adaptation.

In this study, we applied a proteomics method to analyze the acid adaptation response of E. coli O157:H7 TWC01 and evaluate the acid adaptation effect on stx production. The result reveals that acid adaptation improved the survival of $E$. coli O157:H7 TWC01 in $\mathrm{pH} 3.0$ but was not influenced by the poststress toxin production. With 2-DE analysis we found that many proteins were up-regulated in response to acid adaptation, especially in LA-TSB-adapted cells. The metabolic pathway under acid adaptation tended to increase the energy generation to deal with acid condition. The decarboxylase-dependent ARs are major factors in TWC01 resistance to and survival during acid adaptation. This suggests us that foods rich with amino acid could prompt E. coli $\mathrm{O} 157: \mathrm{H} 7$ to become acid resistant once adaptation has happened. Low storage temperature and thorough cooking are always methods to avoid infection. More detailed knowledge about regulation of ATR requires further experimentation. The results of this study are helpful for understanding the acid resistance properties of locally isolated E. coli $\mathrm{O} 157: \mathrm{H} 7$ and improving the control of this pathogen in Taiwan.

\section{LITERATURE CITED}

(1) Padhye, N. V.; Doyle, M. P. Escherichia coli O157:H7: epidemiology, pathogenesis and methods for detection in food. J. Food Prot. 1992, 55, 555-565.

(2) Griffin, P. M.; Tauxe, R. V. The epidemiology of infections caused by Escherichia coli $\mathrm{O} 157: \mathrm{H7}$, other enterohemorrhagic E. coli and the associated hemolytic uremic syndrome. Epidemiol. Rev. 1991, 13, 60-98.

(3) Machin, S. J. Clinical annotation: thrombotic thrombocytopenic purpura. Br. J. Haematol. 1984, 56, 191-197.

(4) Comi, G.; Cocolin, L.; Manzano, M.; Cantoni, C.; Cattaneo, M. Microorganisms behaviour in purposely contaminated fruit juices. Ind. Bevande 2000, 29, 237-246.

(5) Semanchek, J. J.; Golden, D. A. Survival of Escherichia coli O157:H7 during fermentation of apple cider. J. Food Prot. 1996, $59,1256-1259$.

(6) Ryu, J. H.; Beuchat, L. R. Influence of acid tolerance responses on survival, growth, and thermal cross-protection of Escherichia coli $\mathrm{O} 157: \mathrm{H} 7$ in acidified media and fruit juices. Int. J. Food Microbiol. 1998, 45, 185-193.

(7) Glass, K. A.; Loeffelholz, J. M.; Ford, J. P.; Doyle, M. P. Fate of E. coli $\mathrm{O} 157: \mathrm{H} 7$ as affected by $\mathrm{pH}$ or sodium chloride and in fermented, dry sausage. Appl. Environ. Microbiol. 1992, 58, 2513-2516

(8) Arocha, M. M.; McVey, M.; Loder, S. D.; Rupnow, J. H.; Bullerman, L. B. Behavior of hemorrhagic Escherichia coli O157:H7 during the manufacture of cottage cheese. J. Food Prot. 1992, 55, 379-381.

(9) Raghubeer, E. V.; Ke, J. S.; Campbell, M. L.; Meayer, R. S. Fate of Escherichia coli $\mathrm{O} 157: \mathrm{H} 7$ and other coliforms in commercial mayonnaise and refrigerated salad dressing. J. Food Prot. 1995, 58, 13-18.

(10) Lou, Y.; Yousef, A. E. Adaptation to sublethal environmental stress protects Listeria monocytogenes against lethal preservation factors. Appl. Environ. Microbiol. 1997, 63, 1252-1255.

(11) Beales, N. Adaptation of microorganisms to cold temperatures, weak acid preservatives, low $\mathrm{pH}$, and osmotic stress: a review. Compr. Rev. Food Sci. 2004, 3, 1-20.

(12) Sharma, M.; Adler, B. B.; Harrison, M. D.; Beuchat, L. R. Thermal tolerance of acid-adapted and unadapted Salmonella, Escherichia coli $\mathrm{O} 157: \mathrm{H7}$, and Listeria monocytogenes in cantaloupe juice and watermelon juice. Lett. Appl. Microbiol. 2005, 41, 448-453. 
(13) Foster, J. W.; Hall, H. K. Adaptive acidification tolerance response of Salmonella typhimurium. J. Bacteriol. 1990, 172, 771-778.

(14) Benjamin, M. M.; Datta, A. R. Acid tolerance of enterohemorrhagic Escherichia coli. Appl. Env. Microbiol. 1995, 61, 16691672 .

(15) Leyer, G. J.; Wang, L. L.; Johnson, E. A. Acid adaptation of Escherichia coli $\mathrm{O} 157: \mathrm{H} 7$ increases survival in acidic foods. Appl. Environ. Microbiol. 1995, 61, 3752-3755.

(16) Tsai, Y. W.; Ingham, S. C. Survival of Escherichia coli O157: $\mathrm{H} 7$ and Salmonella spp. in acidic condiments. J. Food Prot. 1997, $60,751-755$.

(17) Gorden, J.; Small, P. L. Acid resistance in enteric bacteria. Infect. Immun. 1993, 61, 364-367.

(18) Besser, R. E.; Lett, S. M.; Weber, J. T.; Doyle, M. P.; Barrett, T. J.; Wells, J. G.; Griffin, P. M. An outbreak of diarrhea and hemolytic uremic syndrome from Escherichia coli O157:H7 in fresh-pressed apple cider. JAMA-J. Am. Med. Assoc. 1993, 269 , 2217-2220.

(19) Evans, J.; Wilson, A.; Willshaw, G. A.; Cheasty, T.; Tompkins, D. S.; Wheeler, J. G.; Smith, H. R. Vero cytotoxin-producing Escherichia coli in a study of infectious intestinal disease in England. Clin. Microbiol. Infect. 2002, 8, 183-186.

(20) Duffy, G.; Riordan, D. C. R.; Sheridan, J. J.; Call, J. E.; Whiting, R. C.; Blair, I. S.; McDowell, D. A. Effect of $\mathrm{pH}$ on survival, thermotolerance, and verotoxin production of Escherichia coli O157:H7 during simulated fermentation and storage. J. Food Prot. 2000, 63, 12-13.

(21) Buncic, S.; Avery, S. M. Effects of cold storage and heat-acid shocks on growth and verotoxin 2 production of Escherichia coli O157:H7. Food Microbiol. 1998, 15, 319-328.

(22) Wu, F. T.; Tsai, T. Y.; Hsu, C. F.; Pan, T. M.; Chen, H. Y.; Su, I. J. Isolation and identification of Escherichia coli $\mathrm{O} 157: \mathrm{H} 7$ in a Taiwanese patient with bloody diarrhea and acute renal failure. J. Formosan Med. Assoc. 2005, 104, 206-209.

(23) Leenanon, B.; Drake, M. A. Acid stress, starvation, and cold stress affect poststress behavior of Escherichia coli $0157: \mathrm{H} 7$ and nonpathogenic Escherichia coli. J. Food Prot. 2001, 64, 970-974.

(24) Seputiene, V.; Motiejunas, D.; Suziedelis, K.; Tomenius, H.; Normark, S.; Melefors, O.; Suziedeliene, E. Molecular characterization of the acid-inducible asr gene of Escherichia coli and its role in acid stress response. J. Bacteriol. 2003, 185, 24752484

(25) Tsai, T. Y.; Luo, W. C.; Wu, F. T.; Pan, T. M. Molecular subtyping for Escherichia coli $\mathrm{O} 157: \mathrm{H} 7$ isolated in Taiwan. Microbiol. Immunol. 2005, 49, 579-588.

(26) Goodson, M.; Rowbury, R. J. Habituation to normal lethal acidity by prior growth of Escherichia coli at a sublethal acid $\mathrm{pH}$ value. Lett. Appl. Microbiol. 1989, 8, 77-79.

(27) Bearson, S.; Bearson, B.; Foster, J. W. Acid stress responses in enterobacteria. FEMS Microbiol. Lett. 1997, 147, 173-180.

(28) Cheville, A. M.; Arnold, K. W.; Buchrieser, C.; Cheng, C. M.; Kaspar, C. W. RpoS regulation of acid, heat, and salt tolerance in Escherichia coli O157:H7. Appl. Environ. Microbiol. 1996, $62,1822-1824$.

(29) Diez-Gonzalez, F.; Russell, J. B. The ability of Escherichia coli O157:H7 to decrease its intracellular $\mathrm{pH}$ and resist the toxicity of acetic acid. Microbiology 1997, 143, 1175-1180.
(30) Iyer, R.; Iverson, T. M.; Accardi, A.; Miller, C. A biological role for prokaryotic CIC chloride channels. Nature 2002, 419, 715-718.

(31) Russell, N. J.; Evans, R. I.; Steeg, P. F.; Hellenmons, J.; Verheul, A.; Abee, T. Membranes as a target for stress adaptation. Int. J. Food Microbiol. 1995, 28, 255-261.

(32) Yuk, H. G.; Marshall, D. L. Adaptation of Escherichia coli O157: $\mathrm{H} 7$ to $\mathrm{pH}$ alters membrane lipid composition, verotoxin secretion, and resistance to simulated gastric fluid acid. Appl. Environ. Microbiol. 2004, 70, 3500-3505.

(33) Fang, F. C.; Libby, S. J.; Buchmeier, N. A.; Loewen, P. C.; Switala, J.; Harwood, J.; Guiney, D. G. The alternative $\sigma$ factor KatF (RpoS) regulates Salmonella virulence. Proc. Natl. Acad. Sci. U.S.A. 1992, 89, 11978-11982.

(34) Wilmes-Riesenberg, M. R.; Bearson, B.; Foster, J. W.; Curtiss, $\mathrm{R}$. Role of the acid tolerance response in virulence of Salmonella typhimurium. Infect. Immun. 1996, 64, 1085-1092.

(35) Yuk, H. G.; Marshall, D. L. Influence of acetic, citric, and lactic acids on Escherichia coli O157:H7 membrane lipid composition, verotoxin secretion, and acid resistance in simulated gastric fluid J. Food Prot. 2005, 68, 673-679.

(36) Leenanon, B.; Elhanafi, D.; Drake, M. A. Acid adaptation and starvation effects on shiga toxin production by Escherichia coli O157:H7. J. Food Prot. 2003, 66, 970-977.

(37) Nellemann, L. J.; Holm, F.; Atlung, T.; Hansen, F. G. Cloning and characterization of the Escherichia coli phosphoglycerate kinase (pgk) gene. Gene 1989, 77, 185-191.

(38) Leistner, L. Basic aspects of food preservation by hurdle technology. Int. J. Food Microbiol. 2000, 55, 181-186.

(39) Fraser, H. I.; Kvaratskhelia, M.; White, M. F. The two analogous phosphoglycerate mutases of Escherichia coli. FEBS Lett. 1999, 455, 344-348.

(40) Marie-Pierre, C. C.; Foster, J. W. Escherichia coli acid resistance: cAMP receptor protein and a $20 \mathrm{bp}$ cis-acting sequence control $\mathrm{pH}$ and stationary phase expression of the $\operatorname{gadA}$ and gadBC glutamate decarboxylase genes. Microbiology 2001, 147, 709-715.

(41) Sugawara, E.; Nikaido, H. Pore-forming activity of OmpA protein of Escherichia coli. J. Biol. Chem. 1992, 267, 2507-2511.

(42) Sainz, T.; Perez, J.; Villaseca, J.; Hernandez, U.; Eslava, C.; Mendoza, G.; Wacher, C. Survival to different acid challenges and outer membrane protein profiles of pathogenic Escherichia coli strains isolated from pozol, a Mexican typical maize fermented food. Int. J. Food Microbiol. 2005, 105, 357-367.

(43) Parkinson, J. S.; Kofoid, E. C. Communication moduled in bacterial signaling proteins. Annu. Rev. Genet. 1992, 26, 71112 .

Received for review April 6, 2007. Revised manuscript received May 29, 2007. Accepted June 7, 2007. Proteomic mass spectrometry analyses were performed by the Core Facilities for Proteomics Research located at the Institute of Biological Chemsitry, Academia Sinica, supported by a National Science Council grant (NSC 91-3112-P-001-009-Y) and the Academia Sinica.

JF071014S 